\title{
AKR1C1 Gene
}

National Cancer Institute

\section{Source}

National Cancer Institute. AKR1C1 Gene. NCI Thesaurus. Code C105417.

This gene is involved in the metabolism of aldehydes and ketones. 